Brazilian Journal

of Chemical

Engineering

ISSN 0104-6632

Printed in Brazil

www.abeq.org.br/bjche

Vol. 36, No. 01, pp. 383 - 391, January - March, 2019

dx.doi.org/10.1590/0104-6632.20190361s20170268

\title{
SENSITIVITY ANALYSIS FOR MODEL COMPARISON AND SELECTION IN TISSUE ENGINEERING
}

\author{
Ágata Paim ${ }^{1,2^{*}}$, Nilo S. M. Cardozo ${ }^{1}$, Patricia Pranke ${ }^{2,3}$ and Isabel C. Tessaro ${ }^{1}$ \\ ${ }^{1}$ Universidade Federal do Rio Grande do Sul, Departamento de Engenharia Química, Porto Alegre, RS, Brasil. \\ E-mail: agata@enq.ufrgs.br, ORCID: 0000-0001-5319-7167 \\ ${ }^{2}$ Universidade Federal do Rio Grande do Sul, Faculdade de Fármacia, Porto Alegre, RS, Brasil. \\ ${ }^{3}$ Stem Cell Research Institute, Porto Alegre, RS, Brasil.
}

(Submitted: May 19, 2017 ; Revised: May 26, 2018 ; Accepted: June 10, 2018)

\begin{abstract}
Computational modeling has been proven to be very useful in tissue engineering over the past years. Because the model is a simplification of the experimental system, the processes accounted for in the model should be analyzed carefully. However, new and complex models are usually proposed without a clear comparison with the basic ones. In this study, the contribution of oxygen to Contois growth kinetics and porosity variation with time due to polymer degradation was evaluated through a sensitivity analysis. The effect of initial glucose concentration, porosity and thickness of the scaffold on the cell volume fraction and substrate concentration was analyzed for three models. Even with the inclusion of oxygen concentration in the model, the output variables are more affected by the initial cell number, while the model with variable porosity is quite robust to variations in the input variables.

Keywords: Computational modeling; Tissue engineering; Scaffold porosity; Mass transport; Cell growth.
\end{abstract}

\section{INTRODUCTION}

Modeling techniques have been used recently to determine scaffold properties and/or to analyze the impact of them on tissue development. The properties considered in these works include porosity (Coletti et al., 2006; Yan et al., 2012), permeability (Coletti et al., 2006; Santamaría et al., 2013; Truscello et al., 2012), mean pore size (McCoy et al., 2012; Truscello et al., 2012), surface energy (Decuzzi and Ferrari, 2010), roughness (Decuzzi and Ferrari, 2010) and effective Young's modulus (Gómez-Pachón et al., 2013). Besides this, modeling techniques have also been used in the comparison of different bioreactor designs (Devarapalli et al., 2009; Hidalgo-Bastida et al., 2012; Pathi et al., 2005) and seeding techniques (Chung et al., 2010; Doagă et al., 2008; Jeong et al., 2012). The processes most studied in tissue development are nutrient diffusion and convection (Chung et al., 2008,
2007, 2006; Coletti et al., 2006; Galban and Locke, 1999a, 1999b; Lin et al., 2011; Shakeel, 2011; Yan et al., 2012), cell growth (Chung et al., 2008, 2007, 2006; Coletti et al., 2006; Galban and Locke, 1999a, 1999b; Lin et al., 2011; Shakeel, 2011; Truscello et al., 2012; Yan et al., 2012), cell adhesion strength (Decuzzi and Ferrari, 2010), morphology (McCoy et al., 2012), and cell deformation and detachment (McCoy et al., 2012).

Galban and Locke (1997) used moving boundary equations to develop a mathematical model for cell growth in a porous polymeric matrix. The computational results were compared to the experimental data from Freed et al. (1994), who studied chondrocyte growth kinetics on polyglycolic acid (PGA) scaffolds under static and well-mixed conditions. The authors then improved this model by the inclusion of a nutrient diffusion term to study the performance of different kinetic functions on the prediction of the rate of cell growth (Galban and Locke, 1999b). Using this model,

\footnotetext{
* Corresponding author: Ágata Paim - E-mail: agata@enq.ufrgs.br
} 
the authors evaluated the impact of spatial variation of cell numbers and nutrient and product concentrations on cell growth (Galban and Locke, 1999a).

Chung et al. (2006) developed a mathematical model to describe chondrocyte growth in a porous scaffold. In addition to cell growth kinetics and nutrient consumption, their model included a term for cell diffusion. Chung et al. (2010) considered both glucose and collagen modulation on chondrocyte culture and used the Michaelis-Menten model to describe the glucose uptake. Lin et al. (2011) adapted this model to evaluate the simultaneous effects of glucose and oxygen on cartilaginous constructs under static culture. In these three works the computational results were also compared with the experimental data from Freed et al. (1994). However, in the three cases, this comparison was only performed graphically by means of figures where model predictions and experimental points are plotted together, and without including any comparison with predictions of the other models.

Highly porous scaffolds are desirable for tissue engineering applications because they can support cellular migration and adhesion, promote vascularization, and also encourage angiogenesis. However, the porosity must be optimized because scaffolds with too high void fractions cannot maintain enough mechanical integrity and become unable to support cellular growth (Gluck, 2007). The models based on the volume average method, such as the model proposed by Chung et al. (2006), usually consider the reduction of space for the culture media due to the increase in the cell volume fraction. However, with scaffold degradation and extracellular matrix formation, it becomes interesting to also consider the porosity variation in mathematical models.

Yan et al. (2012) incorporated the effect of scaffold degradation on the porosity of the construct. The data of chondrocytes growth on PGA scaffolds in rotating bioreactors from Freed et al. (1998) were adopted to obtain a porosity function. Although they evaluated the effect of different porosities considering the perfusion of the medium through the scaffold, the model was validated only with the static culture data of Freed et al. (1994). In addition, the behavior obtained for static conditions was less similar to the experimental data from Freed et al. (1994), when compared to the results from Chung et al. (2010) and Lin et al. (2011).

As can be seen, the models for tissue development available in the literature differ greatly from one another with respect to the mechanisms considered and the specific model used for a given mechanism. However, in most cases, each of these models was presented without a detailed comparison with the others, in such a way that the contribution of each model improvement in terms of adequacy or predictive capacity is not completely understood. The overall objective of this work has been to evaluate the contribution of oxygen transport in Contois proliferation kinetics and the porosity variation with time due to polymer degradation, using the model of Chung et al. (2006) considering the Michaelis-Menten model for the nutrient consumption. A sensitivity analysis was used to compare the models and to verify the impact of each variable on the model outputs.

\section{METHODOLOGY}

\section{Modeling}

The governing equations for cell growth, considering only the effect of a random walk on cell diffusion, can be described by the following equation (Chung et al., 2006; Shakeel, 2011; Yan et al., 2012):

$\frac{\partial \varepsilon_{\sigma}}{\partial \mathrm{t}}=\nabla \cdot\left(\mathrm{D}_{\text {eff }, \text { cell }} \nabla \varepsilon_{\sigma}\right)+\left[\mathrm{R}_{\mathrm{g}}-\mathrm{R}_{\mathrm{d}}\right] \varepsilon_{\sigma}$

where $D_{\text {eff,cell }}$ is the diffusion coefficient for random migration of cells, $\varepsilon_{\sigma}$ is the volumetric fraction of cells in the scaffold, $R_{g}$ is the cell growth rate, and $R_{d}$ is the cell death rate.

The classical Contois growth model is widely used for cell growth kinetics (Chung et al., 2006) and is given by Equation 2:

$$
\mathrm{R}_{\mathrm{g}}=\frac{\mu_{\mathrm{max}} \mathrm{C}_{\mathrm{g}, \beta}}{\mathrm{K}_{\mathrm{eq}}^{-1} \mathrm{~K}_{\mathrm{c}} \rho_{\mathrm{cell}} \varepsilon_{\sigma}+\mathrm{C}_{\mathrm{g}, \beta}}
$$

where $\mu_{\max }$ is the maximum cell growth rate, $C_{g, \beta}$ is the average glucose concentration in the fluid phase, $K_{e q}$ is the equilibrium coefficient of the cellular and fluid phases, $\rho_{\text {cell }}$ is the single cell mass density and $K_{c}$ is the Contois saturation coefficient.

When more than one substrate can limit growth kinetics, a double-Contois can be used (Yan et al., 2012). Therefore, considering combined oxygen and glucose modulation of the cell growth rate, this model can be written as:

$$
\mathrm{R}_{\mathrm{g}}=\mu_{\max } \frac{\mathrm{C}_{\mathrm{o}}}{\mathrm{K}_{\mathrm{c}} \rho_{\text {cell }} \varepsilon_{\sigma}+\mathrm{C}_{\mathrm{o}}} \frac{\mathrm{C}_{\mathrm{g}, \beta}}{\mathrm{K}_{\mathrm{eq}}^{-1} \mathrm{~K}_{\mathrm{c}} \rho_{\text {cell }} \varepsilon_{\sigma}+\mathrm{C}_{\mathrm{g}, \beta}}
$$

where $C_{o}$ is the average oxygen concentration in the fluid phase.

The governing equations for glucose and oxygen transport in static culture are given by Equations 4 and 5:

$$
\frac{\partial\left[\left(\varepsilon_{\sigma} \mathrm{K}_{\mathrm{eq}}+\varepsilon_{\beta}\right) \mathrm{C}_{\mathrm{g}, \beta}\right]}{\partial \mathrm{t}}=\nabla \cdot\left[\mathrm{D}_{\mathrm{g}, \mathrm{eff}} \nabla \mathrm{C}_{\mathrm{g}, \beta}\right]-\mathrm{S}_{\mathrm{g}}
$$


$\frac{\partial \mathrm{C}_{\mathrm{o}}}{\partial \mathrm{t}}=\nabla \cdot\left[\mathrm{D}_{\mathrm{o}, \mathrm{eff}} \nabla \mathrm{C}_{\mathrm{o}}\right]-\mathrm{S}_{\mathrm{o}}$

where $C_{g, \beta}$ and $C_{\sigma^{\prime}} D_{g, e f f}$ and $D_{o, e f f}$ and $S_{g}$ and $S_{o}$ are, respectively, the concentration in the culture media, the effective diffusivity in the tissue scaffold, and the volumetric rate of cell consumption of glucose (subindex $g$ ) and oxygen (subindex $o$ ).

The volume fraction of the fluid phase $\left(\varepsilon_{\beta}\right)$ is given by:

$\varepsilon_{\beta}=\varepsilon-\varepsilon_{\sigma}$

where $\varepsilon$ is the scaffold porosity.

For the glucose volumetric rate of cell consumption, Chung et al. (2006) used the following expression:

$\mathrm{S}_{\mathrm{g}}=\mathrm{R}_{\mathrm{m}} \varepsilon_{\sigma} \mathrm{K}_{\mathrm{eq}} \mathrm{C}_{\mathrm{g}, \beta}$

where $R_{m}$ is the glucose uptake rate. The corresponding expression from Michaelis-Menten kinetics is given by (Lin et al., 2011; Yan et al., 2012):

$\mathrm{S}_{\mathrm{g}}=\left[\frac{\mathrm{R}_{\mathrm{gm}} \mathrm{C}_{\mathrm{g}, \beta}}{\mathrm{K}_{\mathrm{gm}}+\mathrm{C}_{\mathrm{g}, \beta}}\right] \varepsilon_{\sigma}$

where $R_{g m}$ is the maximum glucose metabolic rate and $K_{g m}$ is the glucose saturation coefficient.

Similarly, the oxygen volumetric rate of cell consumption is given by:

$\mathrm{S}_{\mathrm{o}}=\left[\frac{\mathrm{R}_{\mathrm{om}} \mathrm{C}_{\mathrm{o}}}{\mathrm{K}_{\mathrm{om}}+\mathrm{C}_{\mathrm{o}}}\right] \varepsilon_{\sigma}$

where $R_{o m}$ is the maximum oxygen metabolic rate and $K_{o m}$ is the oxygen saturation coefficient.

For effective diffusivity, Chung et al. (2006) used the following expression:

$\mathrm{D}_{\mathrm{g}, \mathrm{eff}}=\varepsilon_{\sigma} \mathrm{K}_{\mathrm{eq}} \mathrm{D}_{\mathrm{g}, \sigma}+\varepsilon_{\beta} \mathrm{D}_{\mathrm{g}, \beta}$

where $D_{g, \sigma}$ and $D_{g, \beta}$ are the diffusivities of glucose in the cells and in the fluid phase, respectively.

Conversely, Yan et al. (2012) evaluated the effective diffusivity as:

$\mathrm{D}_{\mathrm{i}, \mathrm{eff}}=\frac{\mathrm{D}_{\mathrm{i}, \mathrm{eff}, \mathrm{m}} \varepsilon}{\tau}$

where $\tau$ is the scaffold tortuosity, and $D_{i, e f f, m}$ is the effective diffusivity of component $i$ in the phase $m$ (cell or fluid), which is evaluated by the Maxwell formula for glucose and oxygen:

$\mathrm{D}_{\mathrm{g}, \mathrm{eff}, \mathrm{m}}=\mathrm{D}_{\mathrm{g}, \beta}\left(\frac{\left(3 \alpha-2\left(\frac{\varepsilon_{\beta}}{\varepsilon}\right)(\alpha-1)\right)}{\left(3+\left(\frac{\varepsilon_{\beta}}{\varepsilon}\right)(\alpha-1)\right)}\right)$,

$\mathrm{D}_{\mathrm{o}, \mathrm{eff}, \mathrm{m}}=\frac{\mathrm{D}_{\mathrm{o}} 2\left(1-\frac{\varepsilon_{\sigma}}{\varepsilon}\right)}{\left(2+\frac{\varepsilon_{\sigma}}{\varepsilon}\right)}$

where $\alpha=K_{e q} \cdot D_{g, \sigma} \cdot D_{g, \beta}{ }^{-I}$ and $D_{o}$ is the oxygen molecular diffusivity in the fluid phase.

The time evolution of the scaffold porosity was evaluated using the function adopted by Yan et al. (2012), which is given by Equation 13:

$\varepsilon=1-\left(1-\varepsilon_{0}\right) \mathrm{e}^{-\mathrm{t} / \Omega}$

where $\varepsilon_{0}$ is the initial porosity of the scaffold, and $\Omega$ is the degradation coefficient.

Based on the previously described set of equations, three models of different levels of complexity were obtained. The mechanisms and equations included in each of these models are summarized in Table 1.

Model I is basically the same as that proposed by Chung et al. (2006), but including the MichaelisMenten kinetics for glucose transport. Model II is similar to the model suggested by Lin et al. (2011), including limitation of growth and the MichaelisMenten kinetics for both glucose and oxygen. Finally, Model III also includes the time dependence of the scaffold porosity as a variable, such as in the model of Yan et al. (2012).

Table 1. Models.

\begin{tabular}{clc}
\hline Model & \multicolumn{1}{c}{ Mechanisms } & Equations \\
\hline I & $\begin{array}{l}\text { Glucose limitation of cell growth } \\
\text { (Contois) }\end{array}$ & 2 \\
& $\begin{array}{l}\text { Glucose transport (Michaelis } \\
\text { Menten) } \\
\text { Glucose and oxygen limitation of } \\
\text { II } \quad \begin{array}{l}\text { cell growth (double Contois) } \\
\text { Glucose and oxygen transport } \\
\text { (Michaelis-Menten) }\end{array}\end{array}$ & 8 \\
III & $\begin{array}{l}\text { Glucose and oxygen limitation of } \\
\text { cell growth (double Contois) } \\
\text { Glucose and oxygen transport } \\
\text { (Michaelis-Menten) } \\
\text { Time dependence of the scaffold } \\
\text { porosity }\end{array}$ & 8,9 \\
\hline
\end{tabular}


As proposed by Chung et al. (2006), the following boundary conditions were specified: (i) zero cell mass flux on the boundaries, and (ii) nutrient concentration at the extremities of the scaffold surface equal to the bulk concentration of the medium surrounding the scaffold. Thus, the nutrient transport occurs from the extremities to the center of the scaffold.

\section{Implementation and Sensitivity Analysis}

Models I-III were implemented in a finite volume code using the open source OpenFOAM package. The numerical scheme used in the simulations was the algorithm for transient processes PIMPLE (Holzmann, 2016). Four rectangular geometries were studied, with proportions between length and height of $3.26 \times 1$, $5.95 \times 1,8.62 \times 1$ and $11.36 \times 1$, corresponding to the cases with thicknesses of $3.07 \times 10^{-3} \mathrm{~m}, 1.69 \times 10^{-}$ ${ }^{3} \mathrm{~m}, 1.16 \times 10^{-3} \mathrm{~m}$ and $0.88 \times 10^{-3} \mathrm{~m}$, respectively. The meshes were created with the tool blockMesh with 100 elements per dimensionless unit of length in each direction, what satisfies the convergence condition, as established preliminarily.

The processes of cell proliferation and nutrient transfer through a PGA scaffold seeded with chondrocytes reported by Freed et al. (1994) were used as the basis of analysis, considering a culture time of 21 days. The set of model parameters used in the simulations is given in Table 2, where the variable $V_{\text {cell }}$ represents the specific cell volume. Considering a static seeding method, an efficiency of $60 \%$ was assumed. The seeding efficiency is the percent of cells that adhere after the cell seeding incubation time and can be expressed by the ratio of cells in the scaffold and the initial cell number.

In the input sensitivity analysis of Models I-III, the influence of four inputs - initial number of cells $\left(\varepsilon_{\sigma, 0}\right)$, scaffold porosity $(\varepsilon)$, scaffold thickness $(H)$, and initial average glucose concentration in the fluid phase $\left(C_{g, 0, \beta}\right)$ - on the output variables (glucose and oxygen concentrations, and volumetric fraction of cells in the scaffold) was evaluated. The sets of different combinations of input values used for the sensitivity analysis are presented in Table 3 , expressed in terms of percentage of the maximum value used for each input. The maximum values used for the initial number of cells, scaffold porosity, scaffold thickness, and average glucose concentration in the fluid phase were, respectively, $\varepsilon_{\sigma, \max }=1 \times 10^{7}$ cells, $\varepsilon_{\max }=100 \%$, $H_{\max }=3.07 \times 10^{-3} \mathrm{~m}$, and $C_{g, 0, \beta, \max }=4.5 \mathrm{~kg} \cdot \mathrm{m}^{-3}$. In all cases an initial oxygen concentration of $0.119 \mathrm{~mol} \cdot \mathrm{m}^{-3}$ was used.

\section{RESULTS AND DISCUSSION}

Figure 1 presents the time evolution of $\varepsilon_{\sigma}$ predicted with Model I for the cases with a scaffold thickness
Table 2. Values of parameters used in the simulations.

\begin{tabular}{|c|c|c|c|}
\hline Parameter & Value & Unit & Reference \\
\hline $\mathrm{D}_{\mathrm{g}, \beta}$ & $1 \times 10^{-8}$ & $\mathrm{~m}^{2} \cdot \mathrm{s}^{-1}$ & $\begin{array}{c}\text { Chung et al. } \\
\text { (2006) }\end{array}$ \\
\hline $\mathrm{D}_{\mathrm{g}, \sigma}$ & $1 \times 10^{-7}$ & $\mathrm{~m}^{2} \cdot \mathrm{s}^{-1}$ & $\begin{array}{c}\text { Chung et al. } \\
\text { (2006) }\end{array}$ \\
\hline Do & $3.093 \times 10^{-7}$ & $\mathrm{~m}^{2} \cdot \mathrm{s}^{-1}$ & $\begin{array}{l}\text { Lin et al. } \\
(2011)\end{array}$ \\
\hline $\mathrm{T}$ & 1.93 & --- & $\begin{array}{c}\text { Yan et al. } \\
\text { (2012) }\end{array}$ \\
\hline$\mu_{\max }$ & $1.6-4.5 \times 10^{-6}$ & $\mathrm{~s}^{-1}$ & $\begin{array}{l}\text { Chung et al. } \\
\text { (2006) }\end{array}$ \\
\hline$\rho_{\text {cell }}$ & $0.182 \times 10^{6}$ & cell $\cdot m^{-3}$ & $\begin{array}{l}\text { Chung et al. } \\
\text { (2006) }\end{array}$ \\
\hline Rom & $1.86 \times 10^{-18}$ & $\begin{array}{l}\mathrm{mol} \cdot \mathrm{s}^{-} \\
{ }^{1} \cdot \mathrm{cell}^{-1}\end{array}$ & $\begin{array}{c}\text { Coletti et al. } \\
\quad(2006)\end{array}$ \\
\hline $\mathrm{R}_{\mathrm{gm}}$ & $8 \times 10^{-3}$ & $\mathrm{~kg} \cdot \mathrm{s}^{-1} \cdot \mathrm{m}^{-3}$ & $\begin{array}{l}\text { Lin et al. } \\
(2011)\end{array}$ \\
\hline $\mathrm{K}_{\mathrm{om}}$ & $6 \times 10^{-3}$ & $\mathrm{~mol} \cdot \mathrm{m}^{-3}$ & $\begin{array}{l}\text { Lin et al. } \\
\text { (2011) }\end{array}$ \\
\hline $\mathrm{K}_{\mathrm{gm}}$ & $6.3 \times 10^{-2}$ & $\mathrm{~kg} \cdot \mathrm{m}^{-3}$ & $\begin{array}{l}\text { Lin et al. } \\
\text { (2011) }\end{array}$ \\
\hline $\mathrm{K}_{\mathrm{c}}$ & 0.154 & --- & $\begin{array}{l}\text { Chung et al. } \\
(2006)\end{array}$ \\
\hline$\Omega$ & $2.1 \times 10^{6}$ & $\mathrm{~s}$ & $\begin{array}{l}\text { Yan et al. } \\
\text { (2012) }\end{array}$ \\
\hline $\mathrm{R}_{\mathrm{d}}$ & $3.3 \times 10^{-7}$ & $\mathrm{~s}^{-1}$ & $\begin{array}{c}\text { Chung et al. } \\
\text { (2006) }\end{array}$ \\
\hline $\mathrm{R}_{\mathrm{m}}$ & $3 \times 10^{-2}$ & $\mathrm{~s}^{-1}$ & $\begin{array}{l}\text { Chung et al. } \\
\text { (2006) }\end{array}$ \\
\hline $\mathrm{V}_{\text {cell }}$ & $5.49 \times 10^{-16}$ & $\mathrm{~m}^{3} \cdot \operatorname{cell}^{-1}$ & $\begin{array}{c}\text { Chung et al. } \\
(2006)\end{array}$ \\
\hline $\mathrm{K}_{\mathrm{eq}}$ & 0.1 & --- & $\begin{array}{c}\text { Chung et al. } \\
(2006)\end{array}$ \\
\hline$D_{\text {eff,cell }}$ & $1.7 \times 10^{-12}$ & $\mathrm{~m}^{2} \cdot \mathrm{s}^{-1}$ & $\begin{array}{c}\text { Chung et al. } \\
(2006)\end{array}$ \\
\hline
\end{tabular}

Table 3. Cases for the sensitivity analysis.

\begin{tabular}{ccccc}
\hline Case & $\begin{array}{c}\boldsymbol{\varepsilon}_{\boldsymbol{\sigma}} / \boldsymbol{\varepsilon}_{\boldsymbol{\sigma}, \max } \\
(\mathbf{\%})\end{array}$ & $\begin{array}{c}\boldsymbol{\varepsilon} / \boldsymbol{\varepsilon}_{\max } \\
(\mathbf{\%})\end{array}$ & $\begin{array}{c}\mathbf{H} / \mathbf{H}_{\max } \\
\mathbf{( \% )}\end{array}$ & $\begin{array}{c}\mathbf{C}_{\mathbf{g}, \mathbf{0}, \boldsymbol{\beta}} / \mathbf{C}_{\mathbf{g}, \mathbf{0 , \beta}, \mathbf{m a x}} \\
(\mathbf{\%} \mathbf{\%})\end{array}$ \\
\hline $\mathrm{A}$ & 40 & 100 & 100 & 100 \\
$\mathrm{~B}$ & 10 & 100 & 100 & 100 \\
$\mathrm{C}$ & 100 & 100 & 100 & 100 \\
$\mathrm{D}$ & 40 & 100 & 100 & 22.22 \\
$\mathrm{E}$ & 40 & 80 & 100 & 100 \\
$\mathrm{~F}$ & 40 & 60 & 100 & 100 \\
$\mathrm{G}$ & 20 & 100 & 28.95 & 100 \\
$\mathrm{H}$ & 20 & 100 & 38.16 & 100 \\
$\mathrm{I}$ & 20 & 100 & 55.26 & 100 \\
$\mathrm{~J}$ & 20 & 80 & 28.95 & 100 \\
$\mathrm{~K}$ & 20 & 80 & 38.16 & 100 \\
$\mathrm{~L}$ & 20 & 80 & 55.26 & 100 \\
$\mathrm{M}$ & 20 & 60 & 28.95 & 100 \\
$\mathrm{~N}$ & 20 & 60 & 38.16 & 100 \\
$\mathrm{O}$ & 20 & 60 & 55.26 & 100 \\
\hline
\end{tabular}

of $3.07 \times 10^{-3} \mathrm{~m}$ (Cases A to F). It can be observed that porosity did not have a significant impact on the cell volume fraction for the Cases A, E and F. According to Gomes et al. (2006), the enhanced cell growth related with highly porous scaffolds is associated to a higher diffusion of nutrients and metabolic waste removal. Thus, in the range of porosity values considered in 


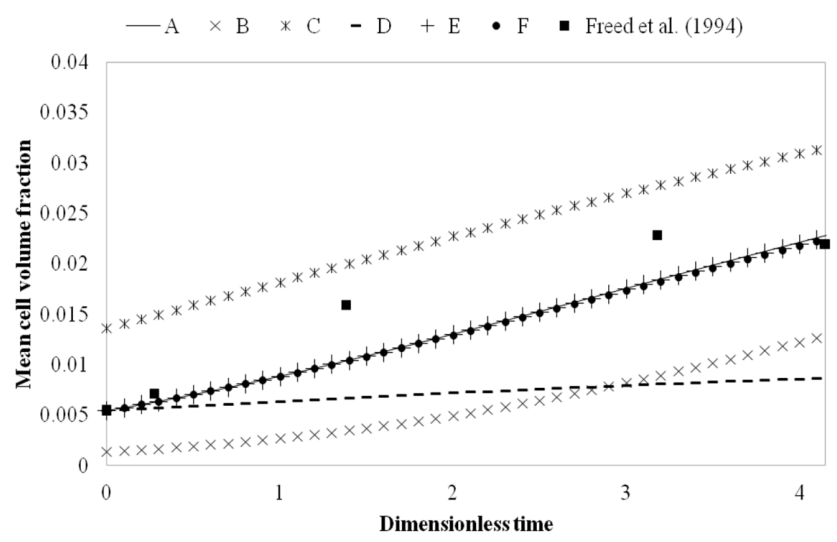

Figure 1. Model I time evolution of mean cell volume fraction for a scaffold thickness of $3.07 \times 10^{-3} \mathrm{~m}$.

this work (100- $60 \%)$ the decrease of porosity would not decrease the nutrient transport sufficiently to affect cell growth. In addition, the production and/or accumulation of toxic metabolites were not considered in this work. Furthermore, with less glucose in the medium at the beginning of the culture (Case D), cell growth is not much higher than cell death, resulting in an almost constant cell volume fraction.

In Figure 2, the dimensionless glucose concentration distribution over the scaffold width at the final time is presented for the cases with a $3.07 \times 10^{-3} \mathrm{~m}$ scaffold thickness in Model I. The increase of mass transport limitation with smaller porosities can be observed through the greater difference between the glucose concentrations at the extremities and at the center of the scaffold observed for Cases $\mathrm{E}$ and $\mathrm{F}$ when compared to Case A.

Mean cell volume fraction presented an increase of $2.3,4.2$, and 9.5 fold in 30 days (corresponding to a 4.15 dimensionless time) for initial cell numbers of $1 \times 10^{7}, 4 \times 10^{6}$ and $1 \times 10^{6}$ cells (Cases C, A and B, respectively). This is in agreement with the behavior observed experimentally by Freed et al. (1994), for which initial cell numbers of $4 \times 10^{7}, 2 \times 10^{7}$ and

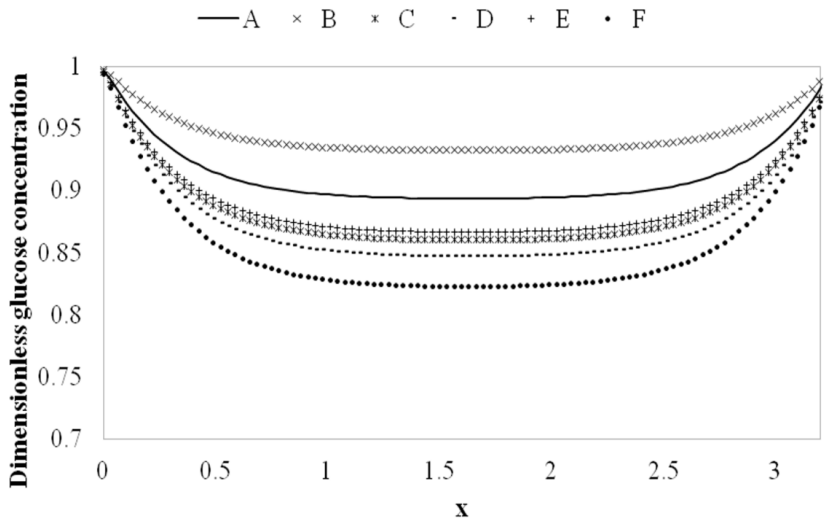

Figure 2. Distribution of dimensionless glucose concentration for scaffolds with $3.07 \times 10^{-3} \mathrm{~m}$ thickness at the final time using Model I.
$0.5 \times 10^{7}$ presented increases of 2.7, 4.2 and 15.8 fold. The increase of cell growth for smaller initial cell density could be due to the higher availability of glucose caused by the smaller consumption. Higher glucose concentrations for Case B (when compared to Cases $\mathrm{A}$ and $\mathrm{C}$ ), with the smallest initial cell number, can be observed in Figure 3, which presents the mean dimensionless glucose concentration evolution with time.

Figure 4 presents the time evolution of $\varepsilon_{\sigma}$ in these cases for Model I. It can be seen that the effect of the porosity on the mean cell volume fraction was much lower than that of the scaffold thickness, as scaffolds of the same thickness presented similar mean cell volume fraction evolution for the three levels of porosity considered: $0.88 \times 10^{-3} \mathrm{~m}(\mathrm{G}, \mathrm{J}$ and $\mathrm{M}), 1.16 \times 10^{-3} \mathrm{~m}(\mathrm{H}$, $\mathrm{K}$ and $\mathrm{N}$ ), and $1.69 \times 10^{-3} \mathrm{~m}$ (I, L and $\mathrm{O}$ ).

As can be observed in Figure 4, the increase in scaffold thickness reduces the initial cell volume fraction when the initial cell number is maintained. Thus, the mean cell volume fraction at the final time is smaller for thicker scaffolds, which is observed for Cases $\mathrm{G}$ to $\mathrm{I}, \mathrm{J}$ to $\mathrm{L}$ and $\mathrm{M}$ to $\mathrm{O}$. The mean cell volume fraction after 30 days in a scaffold with thickness of

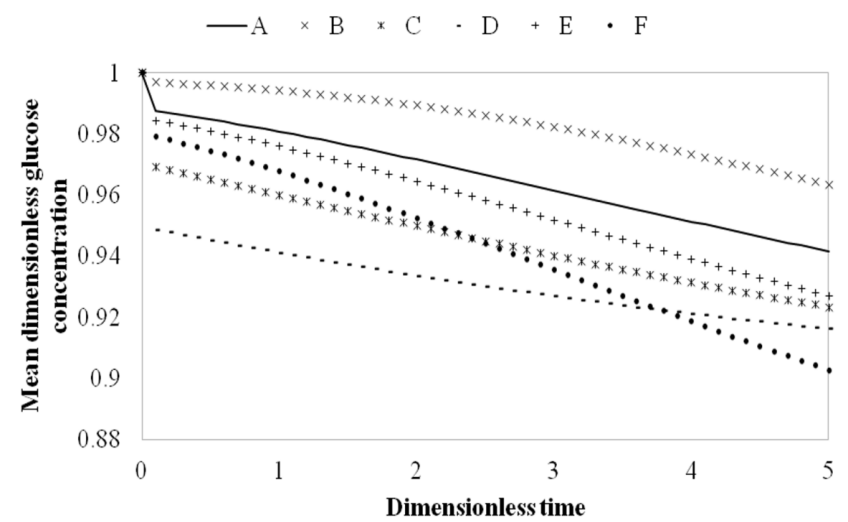

Figure 3. Model I time evolution of the mean dimensionless glucose concentration for a scaffold thickness of $3.07 \times 10^{-3} \mathrm{~m}$.

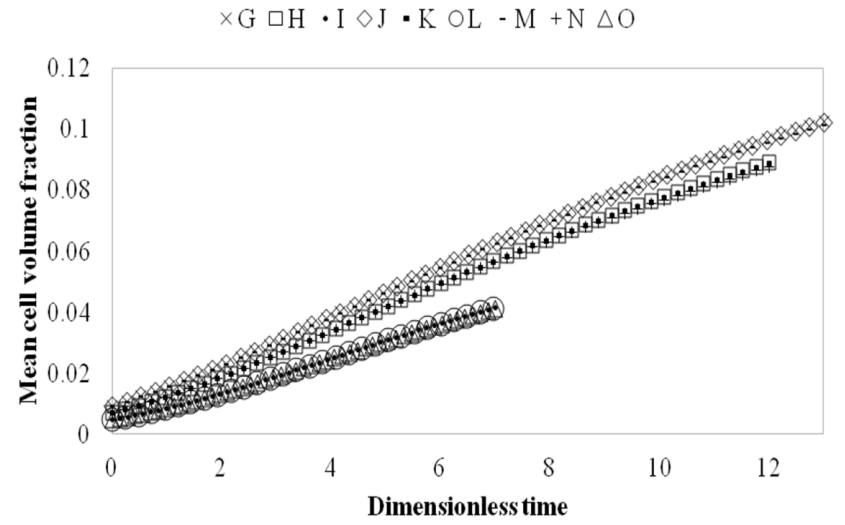

Figure 4. Model I time evolution of the mean cell volume fraction for a scaffold thickness of $0.88,1.16$ and $1.68 \times 10^{-3} \mathrm{~m}$. 
$0.88 \times 10^{-3} \mathrm{~m}$ (Case $\mathrm{G}$ ) is 2.26 fold that obtained with a scaffold of $1.68 \times 10^{-3} \mathrm{~m}$ (Case I), which is comparable to the increase of 2.25-fold observed by Freed et al. (1994). Because Model I does not include oxygen concentration, Model II was used to evaluate the mean dimensionless oxygen concentration evolution with time for scaffolds with a thickness of $3.07 \times 10^{-3} \mathrm{~m}$, as shown in Figure 5. The observed changes of oxygen concentration over time were below $1 \%$. The same occurred for other cases with different thicknesses and also when using Model III. This could be due to a small maximum oxygen consumption rate, which should be estimated for the experimental system under study to check if this parameter is in an acceptable range.

Figure 6 presents the maximum values of mean cell volume fraction deviation obtained with Models II and III when compared to the results obtained with Model I (Figures 1 to 4 ). The values of the cell volume fraction predicted by Model II were slightly smaller than those predicted by Model I, the maximum deviation being approximately $24 \%$ for the thinnest scaffolds (Case G, $\mathrm{J}$ and $\mathrm{M}$ ). Thus, scaffold thickness was the factor that most affected the difference between the predictions of Models I and II, followed by initial glucose concentration and initial cell density. This may be related to the inclusion of the oxygen contribution to the cell growth in the Contois equation, which reduced the effect of glucose concentration on cell growth, and also to the fact that the smaller the scaffold thickness the higher the cell growth and glucose consumption, increasing the difference between the two models.

Cell volume fractions predicted by Model III were also smaller when compared to those obtained with Model I, with a maximum deviation of approximately $38 \%$ for Case M (thinnest and less porous scaffold), as can be seen in Figure 6. Besides this, the differences between the models increased with time and reached the maximum value at the final time for all cases, except Case M with Model III. In Case M, with smaller porosity at the beginning of the culture, the cell growth

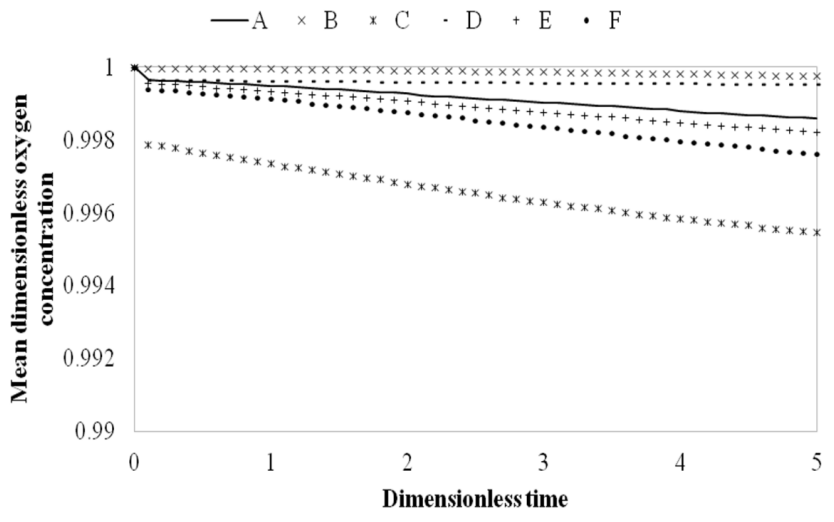

Figure 5. Model II time evolution of the mean dimensionless oxygen concentration for a scaffold thickness of $3.07 \times 10^{-3} \mathrm{~m}$.

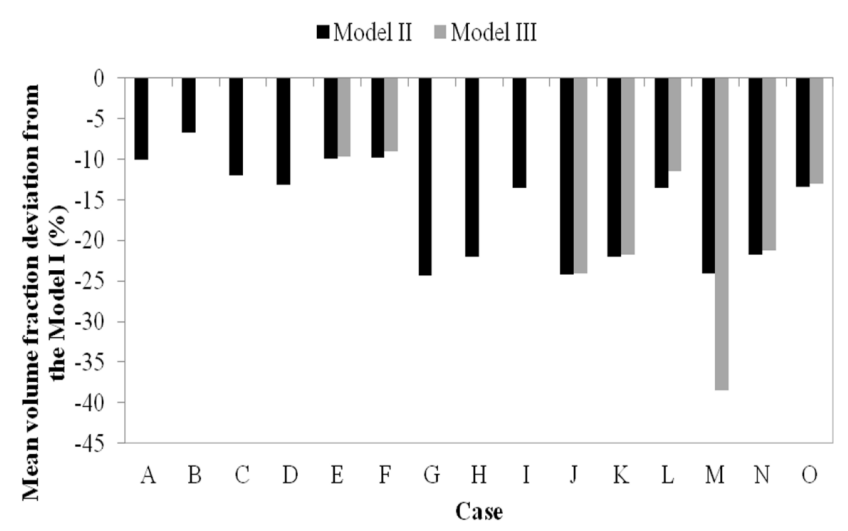

Figure 6. Maximum values of the mean cell volume fraction deviations of Model II and III from Model I for all cases.

was lower, resulting in a higher deviation at the middle of the culture time. As the porosity increases with time, the cell growth increased, reaching the final time with a smaller divergence from Model I.

When the mean cell volume fraction at the final time was compared for different porosities, the effect of the porosity in Model I was slightly more accentuated than that in Models II and III. This could be due to the low oxygen consumption and consequent attenuation of the impact of glucose diffusion limitation on cell growth with the inclusion of a term related to the oxygen concentration in the model (Models II and III). It is important to observe that this effect could be significant with a higher cell growth rate. With polymer degradation and increasing void fraction (Model III), the initial porosity effect was reduced with time.

Figure 7 presents the percent relative errors for the simulation results obtained for the three models when compared to the experimental data of Freed et al. (1994). The smallest mean relative errors obtained with Models II and III were approximately $16 \%$, for the cases with scaffold thickness of $1.16 \times 10^{-3} \mathrm{~m}$. Regarding Model I, the smallest errors (around 17\%) were found for Cases A, E, F, G and J. This is probably due to the fact that the parameter estimation performed

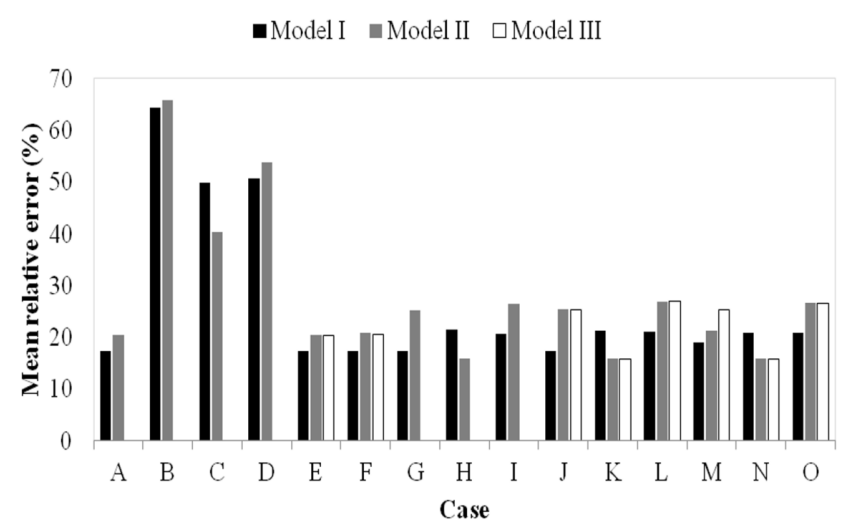

Figure 7. Percent relative errors for Models I, II and III. 
by Chung et al. (2006) with the model without the oxygen term in the Contois equation was based on experimental conditions more similar to those of Case A. The higher mean relative errors obtained for scaffold thicknesses of 1.68 and $1.16 \times 10^{-3} \mathrm{~m}$ may be associated with the inclusion of the Michaelis-Menten equation and the consequent changes in the cell volume fraction profile due to the variable glucose consumption rate. Models II and III seemed to capture the experimental behavior of the cells in scaffolds with $1.16 \times 10^{-3} \mathrm{~m}$ of thickness, which may be related to their smaller cell growth in the initial times.

According to Tables 4-6, Model I presented higher relative errors for intermediate times for Cases A, B, $\mathrm{D}, \mathrm{E}, \mathrm{F}, \mathrm{I}, \mathrm{L}$, and $\mathrm{O}$ and smaller errors at the final time, except for Cases C, D, H, K and N. Case C presented the highest relative error at the smallest time, which

Table 4. Maximum and minimum relative errors from the experimental data of Freed et al. (1994) obtained with Model I.

\begin{tabular}{ccccc}
\hline Case & $\begin{array}{c}\text { Maximum } \\
\text { relative } \\
\text { error (\%) }\end{array}$ & $\begin{array}{c}\text { Normalized } \\
\text { time }\end{array}$ & $\begin{array}{c}\text { Minimum } \\
\text { relative } \\
\text { error (\%) }\end{array}$ & $\begin{array}{c}\text { Normalized } \\
\text { time }\end{array}$ \\
\hline $\mathrm{A}$ & 34.76 & 0.33 & 3.90 & 1.00 \\
$\mathrm{~B}$ & 78.33 & 0.33 & 41.08 & 1.00 \\
$\mathrm{C}$ & 109.04 & 0.07 & 21.55 & 0.77 \\
$\mathrm{D}$ & 64.57 & 0.77 & 19.66 & 0.07 \\
$\mathrm{E}$ & 34.83 & 0.33 & 3.32 & 1.00 \\
$\mathrm{~F}$ & 34.96 & 0.33 & 2.35 & 1.00 \\
$\mathrm{G}$ & 47.59 & 0.07 & 5.12 & 0.77 \\
$\mathrm{H}$ & 51.69 & 1.00 & 8.80 & 0.53 \\
$\mathrm{I}$ & 35.32 & 0.33 & 14.00 & 1.00 \\
$\mathrm{~J}$ & 47.57 & 0.07 & 5.34 & 0.77 \\
$\mathrm{~K}$ & 51.01 & 1.00 & 8.60 & 0.53 \\
$\mathrm{~L}$ & 35.36 & 0.33 & 14.11 & 1.00 \\
$\mathrm{M}$ & 47.55 & 0.07 & 5.73 & 0.77 \\
$\mathrm{~N}$ & 49.83 & 1.00 & 8.25 & 0.53 \\
$\mathrm{O}$ & 35.42 & 0.33 & 13.98 & 1.00 \\
\hline
\end{tabular}

Table 5. Maximum and minimum relative errors from the experimental data of Freed et al. (1994) obtained with Model II.

\begin{tabular}{ccccc}
\hline Case & $\begin{array}{c}\text { Maximum } \\
\text { relative } \\
\text { error (\%) }\end{array}$ & $\begin{array}{c}\text { Normalized } \\
\text { time }\end{array}$ & $\begin{array}{c}\text { Minimum } \\
\text { relative } \\
\text { error (\%) }\end{array}$ & $\begin{array}{c}\text { Normalized } \\
\text { time }\end{array}$ \\
\hline $\mathrm{A}$ & 37.08 & 0.33 & 6.47 & 1.00 \\
$\mathrm{~B}$ & 78.66 & 0.33 & 45.06 & 1.00 \\
$\mathrm{C}$ & 106.66 & 0.07 & 9.42 & 0.77 \\
$\mathrm{D}$ & 68.51 & 0.77 & 20.76 & 0.07 \\
$\mathrm{E}$ & 37.15 & 0.33 & 6.90 & 1.00 \\
$\mathrm{~F}$ & 37.27 & 0.33 & 7.63 & 1.00 \\
$\mathrm{G}$ & 43.79 & 0.07 & 13.64 & 1.00 \\
$\mathrm{H}$ & 24.51 & 0.07 & 6.75 & 0.53 \\
$\mathrm{I}$ & 38.48 & 0.33 & 12.96 & 0.07 \\
$\mathrm{~J}$ & 43.78 & 0.07 & 13.82 & 1.00 \\
$\mathrm{~K}$ & 24.49 & 0.07 & 6.88 & 0.53 \\
$\mathrm{~L}$ & 38.52 & 0.33 & 13.05 & 0.07 \\
$\mathrm{M}$ & 43.76 & 0.07 & 4.52 & 0.53 \\
$\mathrm{~N}$ & 24.47 & 0.07 & 7.11 & 0.53 \\
$\mathrm{O}$ & 38.57 & 0.33 & 12.93 & 0.07 \\
\hline
\end{tabular}

Table 6. Maximum and minimum relative errors from the experimental data of Freed et al. (1994) obtained with Model III.

\begin{tabular}{ccccc}
\hline Case & $\begin{array}{c}\text { Maximum } \\
\text { relative } \\
\text { error (\%) }\end{array}$ & $\begin{array}{c}\text { Normalized } \\
\text { time }\end{array}$ & $\begin{array}{c}\text { Minimum } \\
\text { relative } \\
\text { error (\%) }\end{array}$ & $\begin{array}{c}\text { Normalized } \\
\text { time }\end{array}$ \\
\hline $\mathrm{E}$ & 37.13 & 0.33 & 6.64 & 1.00 \\
$\mathrm{~F}$ & 37.21 & 0.33 & 6.86 & 1.00 \\
$\mathrm{~J}$ & 43.79 & 0.07 & 13.71 & 1.00 \\
$\mathrm{~K}$ & 24.49 & 0.07 & 6.83 & 0.53 \\
$\mathrm{~L}$ & 39.83 & 0.33 & 12.67 & 0.07 \\
$\mathrm{M}$ & 43.76 & 0.07 & 13.79 & 1.00 \\
$\mathrm{~N}$ & 24.47 & 0.07 & 6.93 & 0.53 \\
$\mathrm{O}$ & 38.54 & 0.33 & 12.94 & 0.07 \\
\hline
\end{tabular}

could be related to the consideration of a higher initial cell volume fraction. Model II followed the same behavior as Model I, except for Cases H, I, K, L, N, and O. For Model III, the relative error decreased with time except for Cases $\mathrm{K}$ and $\mathrm{N}$, for which the minimum error occurred for the cell volume fraction at the sixteenth day of cultivation.

The highest mean relative errors were approximately $65 \%$ for the case with the smallest initial cell number (B) for Models I and II, and $26 \%$ for the cases with scaffold thickness of $1.68 \times 10^{-3} \mathrm{~m}(\mathrm{~L}$ and $\mathrm{O})$ for Model III. Thus, Models I and II can be said to be more affected by the initial cell number, while Model III is quite robust to variations in the input variables.

\section{CONCLUSIONS}

The contributions of oxygen to the Contois growth kinetics and the porosity variation with time due to polymer degradation were evaluated through a sensitivity analysis. The inclusion of oxygen concentration in the model affected both the cell volume fraction and the glucose concentration. In addition, the oxygen concentration behavior was not modified by considering a variable porosity in the model. On the other hand, the initial cell number had a more significant impact on mass transport than on cell growth. The inclusion of different processes in the model led to significant differences in the predictions. This indicates that, in order to achieve definitive conclusions in terms of model adequacy and selection, more extensive experimental data generation and specific measuring technique development is required.

\section{ACKNOWLEDGMENTS}

This research was developed at the National Center of Supercomputing from the Federal University of Rio Grande do Sul. The authors would like to thank CAPES (Coordination for the Improvement of Higher Education Personnel), FINEP (Financing Agency for Studies and Projects) and Stem Cell Research Institute for their financial support. 


\section{NOMENCLATURE}

\section{Symbols}

$C_{g, \beta \text {, }}$

$C_{g, 0, \beta}$

$C_{g, 0, \beta, \max }$

$C_{o}$

$C_{o, 0}$

$D_{\text {eff,cell }}$

$D_{g, \beta}$

$D_{g, \sigma}$

$D_{g, e f f}$

$D_{g, e f f, \beta}$

$D_{g, e f f, \sigma}$

$D_{o}$

$D_{o, e f f}$

$D_{o, e f f, \beta}$

$D_{o, e f f, \sigma}$

H

$H_{\text {max }}$

$K_{c}$
$K_{e q}$

$K_{g}$

$K_{\text {om }}$

$R_{d}$

$R_{g}$

$R_{g m}^{g}$

$R_{m}$

$R_{\text {om }}^{m}$

$S_{g}$

$S_{o}$

$V_{\text {cell }}$ average glucose concentration in the

fluid phase, $\mathrm{kg} \cdot \mathrm{m}^{-3}$

initial average glucose concentration

in the fluid phase, $\mathrm{kg} \cdot \mathrm{m}^{-3}$

maximum value used for the initial

average glucose concentration in the

fluid phase, $\mathrm{kg} \cdot \mathrm{m}^{-3}$

average oxygen concentration in the

fluid phase, $\mathrm{mol} \cdot \mathrm{m}^{-3}$

initial average oxygen concentration, $\mathrm{mol} \cdot \mathrm{m}^{-3}$

coefficient for random migration of

cells, $\mathrm{m}^{2} \mathrm{~s}^{-1}$

glucose diffusivity in the fluid phase, $\mathrm{m}^{2} \mathrm{~s}^{-1}$

glucose diffusivity in the cell phase, $\mathrm{m}^{2} \mathrm{~s}^{-1}$

glucose effective diffusivity in the tissue scaffold, $\mathrm{m}^{2} \mathrm{~s}^{-1}$

glucose effective diffusivity in the

fluid phase, $\mathrm{m}^{2} \mathrm{~s}^{-1}$

glucose effective diffusivity in the

cell phase, $\mathrm{m}^{2} \mathrm{~s}^{-1}$

oxygen molecular diffusivity in the

fluid phase, $\mathrm{m}^{2} \mathrm{~s}^{-1}$

oxygen effective diffusivity in the

tissue scaffold, $\mathrm{m}^{2} \mathrm{~s}^{-1}$

oxygen effective diffusivity in the

fluid phase, $\mathrm{m}^{2} \mathrm{~s}^{-1}$

oxygen effective diffusivity in the cell phase, $\mathrm{m}^{2} \mathrm{~s}^{-1}$

scaffold thickness, $\mathrm{m}$

maximum value used for the scaffold

thickness, $\mathrm{m}$

Contois saturation coefficient

equilibrium coefficient of the cellular and fluid phases

glucose saturation coefficient, $\mathrm{kg} \cdot \mathrm{m}^{-3}$

oxygen saturation coefficient, $\mathrm{mol} \cdot \mathrm{m}^{-3}$

cell death rate, $\mathrm{s}^{-1}$

cell growth rate, $\mathrm{s}^{-1}$

maximum glucose metabolic rate, $\mathrm{g} \cdot \mathrm{s}^{-1} \cdot \mathrm{m}^{-3}$

glucose uptake rate, $\mathrm{s}^{-1}$

maximum oxygen metabolic rate, $\mathrm{mol} \cdot \mathrm{s}^{-1} \cdot \mathrm{cell}^{-1}$

volumetric rate of cell consumption

for glucose, $\mathrm{kg} \cdot \mathrm{s}^{-1} \cdot \mathrm{m}^{-3}$

volumetric rate of cell consumption

for oxygen, $\mathrm{mol} \cdot \mathrm{s}^{-1} \cdot \mathrm{cell}^{-1}$

specific cell volume, $\mathrm{m}^{3} \cdot$ cell $^{-1}$

\section{Greek letters}

$\alpha$

parameter from the Maxwell formula for glucose effective diffusivity

scaffold porosity

initial scaffold porosity

fluid phase volume fraction

volumetric fraction of cells in the scaffold

initial number of cells, cells

maximum value used for the initial number of cells

maximum value used for the scaffold porosity

single cell mass density, cell $\cdot \mathrm{m}^{-3}$

maximum cell growth rate, $\mathrm{s}^{-1}$

scaffold tortuosity

degradation coefficient, $\mathrm{s}$

\section{REFERENCES}

Chung, C.A., Chen, C.P., Lin, T.H., and Tseng, C.S., A compact computational model for cell construct development in perfusion culture, Biotechnol. Bioeng., 99, 1535-1541 (2008). https://doi. org/10.1002/bit.21701

Chung, C.A., Chen, C.W., Chen, C.P., and Tseng, C.S., Enhancement of cell growth in tissue-engineering constructs under direct perfusion: Modeling and simulation, Biotechnol. Bioeng., 97, 1603-1616 (2007). https://doi.org/10.1002/bit.21378

Chung, C.A., Lin, T.-H., Chen, S.-D., and Huang, H.I., Hybrid cellular automaton modeling of nutrient modulated cell growth in tissue engineering constructs, J. Theor. Biol., 262, 267-278 (2010). https://doi.org/10.1016/j.jtbi.2009.09.031

Chung, C.A., Yang, C.W., and Chen, C.W., Analysis of Cell Growth and Diffusion in a Scaffold for Cartilage Tissue Engineering, Wiley Period, 94, 1138-1146 (2006). https://doi.org/10.1002/ bit.20944

Coletti, F., Macchietto, S., and Elvassore, N., Mathematical Modeling of Three-Dimensional Cell Cultures in Perfusion Bioreactors, Ind. Eng. Chem. Res., 45, 8158-8169 (2006). https://doi. org/10.1021/ie051144v

Decuzzi, P., and Ferrari, M., Modulating cellular adhesion through nanotopography, Biomaterials, 31, 173-179 (2010). https://doi.org/10.1016/j. biomaterials.2009.09.018

Devarapalli, M., Lawrence, B.J., and Madihally, S. V., Modeling nutrient consumptions in large flow-through bioreactors for tissue engineering, Biotechnol. Bioeng., 103, 1003-1015 (2009). https://doi.org/10.1002/bit.22333

Doagă, I.O., Savopol, T., Neagu, M., Neagu, A., and Kovács, E., The kinetics of cell adhesion to 
solid scaffolds: An experimental and theoretical approach, J. Biol. Phys., 34, 495-509 (2008). https://doi.org/10.1007/s10867-008-9108-x

Freed, L.E., Hollander, A.P., Martin, I., Barry, J.R., Langer, R., and Vunjak-Novakovic, G., Chondrogenesis in a cell-polymer-bioreactor system, Exp. Cell Res., 240, 58-65 (1998). https:// doi.org/10.1006/excr.1998.4010

Freed L.E., Marquis J.C., Langer, R., and VunjakNovakovic, G, Kinetics of chondrocyte growth in cell-polymer implants, Biotechnol Bioeng., 43(7), 597-604 (1994). https://doi.org/10.1002/ bit.260430709

Galban, C.J., and Locke, B.R., Analysis of cell growth kinetics and substrate diffusion in a polymer scaffold, Biotechnol. Bioeng., 65, 121-132 (1999a). https://doi.org/10.1002/ (SICI) 1097-0290(19991020)65:2\%3C121::AIDBIT1\%3E3.0.CO;2-6

Galban, C.J., and Locke, B.R.,Effects of spatialvariation of cells and nutrient and product concentrations coupled with product inhibition on cell growth in a polymer scaffold, Biotechnol. Bioeng., 64, 633-643 (1999b). https://doi.org/10.1002/ (SICI) 1097-0290(19990920)64:6\%3C633::AIDBIT1\%3E3.0.CO;2-6

Galban, C.J., and Locke, B.R., Analysis of cell growth in a polymer scaffold using a moving boundary approach, Biotechnol. Bioeng., 56, 422-432 (1997). https://doi.org/10.1002/ (SICI) 1097-0290(19971120)56:4\%3C422::AIDBIT7\%3E3.0.CO;2-Q

Gluck, J.M., Electrospun Nanofibrous Poly( $\varepsilon-$ caprolactone) (PCL) Scaffolds for Liver Tissue Engineering. Master Thesis, Graduate Faculty of North Carolina State University (2007).

Gomes, M.E., Holtorf, H.L., Reis, R.L., and Mikos, A.G., Influence of the porosity of starch-based fiber mesh scaffolds on the proliferation and osteogenic differentiation of bone marrow stromal cells cultured in a flow perfusion bioreactor, Tissue Eng., 12, 801-809 (2006). https://doi.org/10.1089/ ten.2006.12.801

Gómez-Pachón, E.Y., Sánchez-Arévalo, F.M., Sabina, F.J., Maciel-Cerda, A., Campos, R.M., Batina, N., Morales-Reyes, I., and Vera-Graziano, R., Characterisation and modelling of the elastic properties of poly(lactic acid) nanofibre scaffolds, J. Mater. Sci., 48, 8308-8319 (2013). https://doi. org/10.1007/s10853-013-7644-7
Hidalgo-Bastida, L.A., Thirunavukkarasu, S., Griffiths, S., Cartmell, S.H., and Naire, S., Modeling and design of optimal flow perfusion bioreactors for tissue engineering applications, Biotechnol. Bioeng., 109, 1095-1099 (2012). https://doi. org/10.1002/bit.24368

Holzmann, T., The pimple algorithm in OpenFOAM (2016). https://openfoamwiki.net/index.php/ OpenFOAM_guide/The_PIMPLE_algorithm_in OpenFOAM (accessed 7.14.16).

Jeong, D., Yun, A., and Kim, J., Mathematical model and numerical simulation of the cell growth in scaffolds, Biomech. Model. Mechanobiol., 11, 677-688 (2012). https://doi.org/10.1007/s10237011-0342-y

Lin, T.-H., Lin, C.-H., and Chung, C.A., Comutational Study of Oxygen and Glucose Transport in Engineered Cartilage Constructs, J. Mech., 27, 337346 (2011). https://doi.org/10.1017/jmech.2011.36

McCoy, R.J., Jungreuthmayer, C., and O'Brien, F.J., Influence of flow rate and scaffold pore size on cell behavior during mechanical stimulation in a flow perfusion bioreactor, Biotechnol. Bioeng., 109, 15831594 (2012). https://doi.org/10.1002/bit.24424

Pathi, P., Ma, T., and Locke, B.R., Role of nutrient supply on cell growth in bioreactor design for tissue engineering of hematopoietic cells, Biotechnol. Bioeng., 89, 743-758 (2005). https:// doi.org/10.1002/bit.20367

Santamaría, V.A.A., Malvè, M., Duizabo, a., Mena Tobar, a., Gallego Ferrer, G., García Aznar, J.M., Doblaré, M., and Ochoa, I., Computational methodology to determine fluid related parameters of non regular three-dimensional scaffolds, Ann. Biomed. Eng., 41, 2367-2380 (2013). https://doi. org/10.1007/s10439-013-0849-8

Shakeel, M., Continuum modelling of cell growth and nutrient transport in a perfusion bioreactor. $\mathrm{PhD}$ Thesis. The University of Nottingham (2011).

Truscello, S., Kerckhofs, G., Van Bael, S., Pyka, G., Schrooten, J., and Van Oosterwyck, H., Prediction of permeability of regular scaffolds for skeletal tissue engineering: A combined computational and experimental study, Acta Biomater., 8, 1648-1658 (2012). https://doi.org/10.1016/j. actbio.2011.12.021

Yan, X., Bergstrom, D.J., and Chen, X.B., Modeling of cell cultures in perfusion bioreactors, IEEE Trans. Biomed. Eng., 59, 2568-2575 (2012). https://doi. org/10.1109/TBME.2012.2206077 
